\title{
人々の心理要因に着目したカーシェアリングの効果的な加入促進に対する研究*
}

A study of promotion method to encourage carsharing focused on psychological factors*

\author{
太田裕之 $* * \cdot$ 藤井聡 $* * * \cdot$ 遠藤弘太郎 $* * * * \cdot 土$ 居厚司 $* * * * * *$ \\ By Hiroyuki Ohta** • Satoshi FUJII *** • Kotaro ENDO***** Atsushi DOI ${ }^{* * * * * *}$
}

1.はじめに

過度に自動車に依存した社会の整害として, 地球温暖 化問題を初めとし, 都市のスプロール化, 慢性的な交通 渋滞等, 樣々な問題力顕在化してきている.今後, 持続 可能な交通社会の構築を目指すには，この過度な自動車 依存状況からの脱却を図ることか求められている .この ような認識から，昨今モビリティ・マネジメント ${ }^{1)}$ (以 下，MM)が, 樣々な地域で実施され，「かしこいクル マの使い方」に向け, 交通手段の変容や, 目的地の変更, 活動内容自体の見直しなど樣々な形態の行動変容を誘発 し，実質的な効果をあげてきている2).

このような「かしこいクルマの使い方」に向けたモー ダルシフトは, MM において重要な施策であるが, MM が「かしこいクルマの使い方」を促すものである以上，

「クルマ兴のものをかしこく使う」方向へのアプローチ も検討せざるを得ないところである，弚の一例として， 自動車の所有形態を変えるという，より抜本的な行動変 容が考えられるが, 自動車を“手放す”ような大きな変 化を多くの自動車保有者に期待することは, 必ずしも容 易でないものと考えられる. 并れ故，1台の自動車を複 数の人々で共有・共用するという新しい自動車の保有・ 利用形態である「カーシェアリング」は自動車の保有形 態の変容において重要な役割を担うことか期待される．

カーシェアリングでは, 1 台の自動車を複数の人々が 共同て使用するため, 自動車の購入費や駐車場費力抑え られる等, マイカー保有と比べ, 格安て個別のモビリテ イカ浰用可能となる . また同時に, カーシェアリンク加 入によって, 不要な自動車保有や利用力削減され, 道路

\footnotetext{
*キーワーズ : MM カーシェアリング、自動車保有、意識調査分析

**正員 (工博) 東京工業大学大学院理工学研究科土木工学専攻

( 現; 国土交通省東北地方整備局能代河川国道事務所

Enail : oota h82ac@hr. mi t. go.j p)

*** 正員 (工博) 京都大学大学院工学研究科都市社会工学専攻

( ( 615.8540 京都市西京区京都大学桂4

TEL: 075-383 3241, Enai I : fuj i i @ r ans. kuci v. kyoto- u. ac.j p)

**** 正員( 工修) (妹)ライテック社会・公共ソリューション部

( ₹102-0074 東京都千代田区九段南4丁目7番2号

TEL : 03-3263-5418, FAX : 03-3263-5515)

*****(㧣)ライテック社会・公共ソリューション部
}

渋滞や大気污染問題の緩和， $\mathrm{CO}_{2}$ 排出削缄など，樣々な 社会的メリットをもたらすことか国内外の各種事例より 報告されている ${ }^{3)}{ }^{4)}$,5) . つまり，一人一人がマイカ一保 有から , カーシェアリンク利用へと移行することにより， 現在の自動車過乗状態からより望ましい社会状況へシフ トしていくことが可能になると考えられる .

このカーシェアリングは, スイスを発祥とし, 現在 欧米を中心に普及しつつある の . 我か国においては， 1999 年の電気自動車を用いた社会実験に端を発し，現 在では, 主に事業ベースて運営されている ーシェアリングの運営について, 我力国ては, 主に完全 自動化て行われており，この技術的側面に関しては欧米 諸国に比して既に先進的であると考えられるの。

しかしながら, 例えば, 2005 年時の名古屋のカーシ ェアリングにおいて，「非会員のうちカーシェアリング

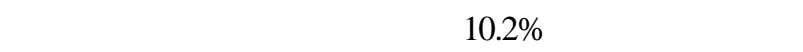
果 ${ }^{8)}$ や, 全国の免許保有者を対象とした 2007 年の調査 において「40.4\%の回答者がカーシェアリングを全く知 らない」との結果 ${ }^{9)}$ が示唆するように，日本における カーシェアリングは, 現状では炎の新規性故に, まだ十 分な理解が一般に広く浸透しているとは言い難し 状況で ある. また，会員数も全国で 6,396 人 (2009 年 1 月時 点) と限定的な水準に留まっている ${ }^{10)}$.

以上を踏まえれば, カーシェアリングのシステム面で の改良よりもむしろ，いまだ十分でない認知度の向上を はじめとし , カーシェアリングをいかにして普及させて いくか，といった対策を講じることが，我国において 極めて重要な点であると考えられる . 光こで, 本研究で は, 社会実験として, オリックス自動車(株) のカーシ エアリングシステムか潘入された地域において, 併せて 「ワンショットTFP」を実験的に実施することとした． そして，これまで主としてモーダルシフトに活用されて きたこの TFP 技術が, 自動車保有に関わるカーシェア リンク加入行動の誘発に援用できるか否かについて基 礎的な知見を得ることを目的として, 主としてアンケー 卜調査で得られた心理データの分析，ならびに，TFPの 有無による実行動の比較を行う.

\section{2. 実施概要}


表-1 カーシェアリンク加入促進 TFP実験 実施条件

\begin{tabular}{|c|c|c|c|c|}
\hline \multirow{3}{*}{ 配布群 } & \multirow{3}{*}{ 配布物 } & \multicolumn{3}{|c|}{ 配布数 } \\
\hline & & $\begin{array}{c}\text { 世帯 } \\
\text { ポスブス }\end{array}$ & & 配布) \\
\hline & & \begin{tabular}{l|} 
画駅共通】 \\
\end{tabular} & 橋本 & 相模大野! \\
\hline TFP群 & 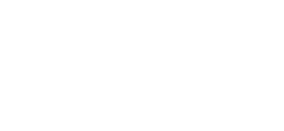 & 700 & 41 & 95 \\
\hline チラシ群 & $\begin{array}{l}\text { (1)CS紹介リーフフルット } \\
\text { (2)駐車場周边地図 }\end{array}$ & 700 & 41 & 95 \\
\hline 制御群 & なし & 700 & 40 & 94 \\
\hline
\end{tabular}

本研究ては, 環境省「平成 19 年度神奈川県地域にお ける EST モデル事業推進のための普及啓発委託業務」 の一環として , カーシェアリンク加入促進のための「ワ ンショット TFP」を実施した .なお，ワンショット TFP とは, TFP のうち, 1 回のみのコンタクトで完結する最 も簡易な TFP である ${ }^{1)}$. 実施地域は, 神奈川県相模原市 内の, 橋本駅(JR 横浜線・相模線), 相模大野駅(小田急 電鉄小田原線・江ノ島線)の 2 駅弚れの駅周辺に配 置された駐車場(デポ)より，500m 以内の範囲とした . TFP ツールとしては，1) 動機付冊子，2) コミュニケー ション・アンケート，3）挨拸状，4）返信用封筒，5) 個 人情報保護規約を同封した .これらの詳細についてはお つて述べる。

また , 加入効果計測の為 , カーシェアリングの紹介リ 一フレット・駐車場地図のみを配布する「チラシ群」，

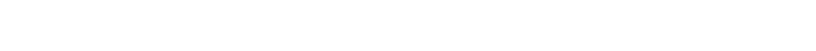
同数程度設けた . 以上の実験条件について表-1にまと める.なお, TFP ツール, および, チラシ類の配布は 2008 年 1 月末頃に実施した. 対象は, 居住者, および, 事業所とし，居住者に対してはポスティングにより，各

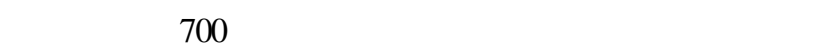
で電咊帳より抽出し，郵送により，橋本駅では 41 件， 相模大野駅では 95 件に TFP ツールを配布した . コミュ ニケーション・アンケートの返送締め切りは 2 月中旬頃 に設定した。

なお，表 1 に示したように，本研究ではアンケートを 配布したのは TFP 群のみであり，アンケート結果につ いての群間比較を行うことができないが, 当然ながら， カーシェアリング運営会社に対する具体的な「資料請 求」はいずれの群からも実行可能であるため, この視点 から群間の比較を行うことを通じて，TFP の有効性，な らびに, 弚のチラシとの相違やチラシの有效性を検証す ることとした .

\section{(1) 動機付け冊子}

カーシェアリング加入に対する動機付けを目的とし， A5 版 8 ページ(表紙含む)の小冊子を同封した . 冊子内 では, 初めに, カーシェアリングとは何か, について簡 単に説明した上で, 弚の使い方, レンタカーとの相違に つての解説を行った . 弚の後, カーシェアリングのメ
リットとして , マイカーを保有する場合と比較した場合 のカーシェアリングの費用面でのメット (カーシェア リングとオカネ) , および, カーシェアリンク加入前後 による会員の総走行距離の減少量から推計した $\mathrm{CO} 2$ 排 出削減効果 (カーシェアリングと環境問題) を, 弚れぞ れ具体的数值データを掲載したグラフと併せて提示した 。 乥して最後にカーシェアリンク加入の検討を推奨した .

なお，費用面でのメリットに関しては「軽自動車を 購入する場合よりも, 1 力月間で, $3 \sim 4$ 万円程度, 10 年 間だと 400 500 万円程度も安くなる」との情報を，CO2 排出削減効果ては,「カーシェアリンク加入前後で一人 当たり $\mathrm{CO} 2$ 排出量が 1 日換算て約 $5.2 \mathrm{~kg}$ 削減される」 との情報を提示した .これら数値データの算出にあたつ ては，オリックス自動車(株) ホーム・ページ ${ }^{11)}$ ，およ び, カーシェアリングによる環境負荷低減効果及ひ普及 方策検討報告書( 交通エコロジー・モビリティー財 団,2006) 尚を参照した。

（2）コミュニケーション・アンケート

コミュニケーション・アンケートては, 居住者には

「クルマを買ったことがある人」，事業所には「自動車 の管理担当者」に回答の協力を要請した . 設問の構成は， 以下の通りである .

初めに, カーシェアリングの「認知度」を尋ね, 続 けて，動機付け冊子内て紹介したカーシェアリングのメ リットに関する情報「カーシェアリングとオカネ」「カ ーシェアリングと環境問題」についての興味を尋ねるこ とを通じて動機付け冊子の読了誘導を行った . 光の後, カーシェアリングに対する「理解度」, カーシェアリン グへの「加入意向」を尋ねた .

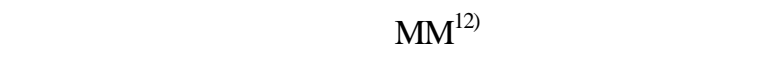
自動車利用といった習慣からの転換を図る場合，コミュ ニケーションを図るタイミングは重要な要素であり，特 に，マイカーからカーシェアリングへの転換を図る上で は, 自動車の新規購入時や買換時 , セカンドカ一等の増 車時といった意思決定時点での働きかけが重要になると 考えられる. 产のため, 自動車の新規購入時や買換時, セカンドカ一等の増車時といった樣々な時点において， カーシェアリングの加入可能性を尋ねることを通じ, 加 入意識 (行動意図) の活性化を図った .

乥して最後に, 最寄り駅 (橋本駅または相模大野駅) 周辺のカーシェアリングについての関心度を尋ね, 関心 が少しでもあり，かつ，より詳細な情報を希望する場合 には送付先と氏名の記入を要請した .これらを通じ, 実 際の加入意向 (実行意図) の促進を図った .

なお，弚の他の基礎情報として，居住者に対しては， 年齢・性別・家族構成・自動車保有台数について, 事業 所に対しては業種・従業員数・自動車保有台数を尋ねた。 
表 2 アンケート回収数 $\cdot$ 回収率

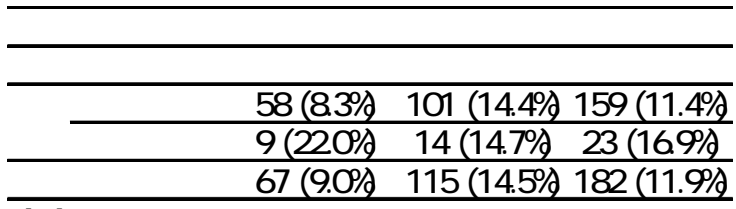

[注] 括弧内は回収率を示す

表- 3 カーシェアリンク認知度

\begin{tabular}{rrrrrrrr}
\hline & \multicolumn{2}{c}{ 橋本駅 } & \multicolumn{2}{c}{ 相模大野駅 } & \multicolumn{2}{c}{ 合計 } \\
\hline & $\mathrm{N}$ & $\%$ & $\mathrm{~N}$ & $\%$ & $\mathrm{~N}$ & $\%$ \\
\hline 全〈知らなかった & 27 & $40.91 \%$ & 36 & $31.30 \%$ & 63 & $34.81 \%$ \\
\hline 少し知っていた & 26 & $39.39 \%$ & 37 & $32.17 \%$ & 63 & $34.81 \%$ \\
\hline r知っていた & 13 & $19.70 \%$ & 42 & $36.52 \%$ & 55 & $30.39 \%$ \\
\hline 合計 & 66 & $100 \%$ & 115 & $100 \%$ & 181 & $100 \%$ \\
\hline
\end{tabular}

\section{3. 実施結果}

本研究て対象としたカーシェアリングシステムは, 当 初, 継続予定ではあったが, 諸事情のため継続力困難と なってしまい, TFP 実施 2 力月後の 3 月で当該地域より 撤退することとなってしまった . 产のため, 今回の実験 では, 実際のカーシェアリンク加入行動に対する TFP 効果を計測することか困難であったが, アンケート結果 よりカーシェアリンク普及に資する知見か得られたため， 以下では, 光の内容について述べる.

\section{(1) アンケート返送結果}

対象別, 駅別のアンケート回収数, 回収率を表-2に示 す.表-2より，全体の回收数は182件 (回收率11.9\%) で あり, 居住者ては相模大野駅の方が , 事業所ては橋本駅 の方が高い回収率となっている .なお, 回収率の違いの 一因として , 居住者では100世帯以上が居住する大型団 地やマンション(同一箇所て群分けしたため $1 / 3$ がンケ 一ト対象)が，相模大野では7割班度(481件/700件)を占め るのに対し，橋本駅では2割程度(133件/700件)であると いったことが考えられる . 居住者を対象としたアンケー 卜回答者の平均年齢は51.62歳(標準編差13.24)であり， 男性か $76.4 \%(\mathrm{~N}=120)$ を占めている.一方, 事業所対象 のアンケート回答者について 従業員数 10 名末満が 12 件，10名以上 50 名未満が4件, 50 名以上が4件(50名:2 件,58名:1件,140名:1件)であり，中小規模の事業所からの 回答となっている .なお, 業種はサービス業, ビル管理 業, 医療関連, 建設関連, 販売業, 警備業, 理容業, 金 融業, 税理士業, 公務員であった。

\section{(2) カーシェアリンク認知度}

コミュニケーション・アンケートでは, まず，“「カ ーシェアリング」をこ存知でしたか?”との文言により， カーシェアリング認知度を尋ねた . 回答結果を表-3に 示す. 表-3 より，相模大野駅のほうか橋本駅よりも， やや認知度か高い，これは, 相模大野駅では当実験時以 前 (2005 年) に既にカーシェアリングか導入されていた

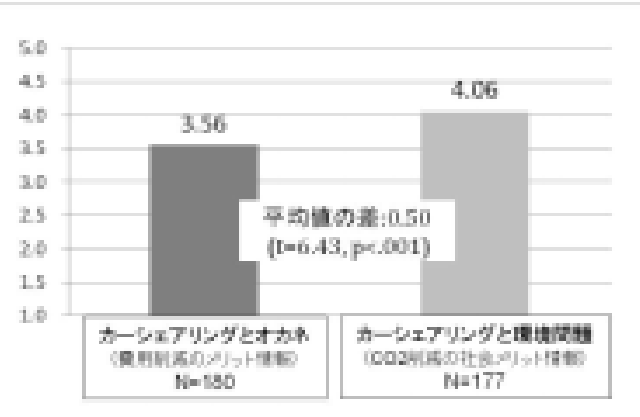

図 1各メリット情報に対する興味に関する平均值

ことがある一方で, 橋本駅では今回初めて導入されたと いった違いがあることが一つ原因として考えられる． ただし，どちらの駅においても，回答者のうち 30\%以 上がカーシェアリングを「全く知らなかった」と回答し ている . 炎のため , カーシェアリング普及を進めるにあ たり，まずは, カーシェアリング产のものについての認 知を十分に広めるためのコミュニケーション施策等が， まだまだ必要であると考えられる .

\section{（3）動機付け冊子内の各テーマへの興味}

次に, 動機付け冊子て紹介した , カーシェアリングの 費用面でのメリットに関する情報 (カーシェアリングと オカネ), および $\mathrm{CO} 2$ 削減効果に関する情報 (カーシェ アリングと環境問題) に対する興味につい,「全く興 味なし(1)」から「とても興味深い(5)」の 5 段階で回答 を要請 した .どちらの情報についても，関心度の平均 値に駅間での差異はみられなかったため (カーシェアリ ングとオカネ : $\mathrm{t}=0.63(\mathrm{p}=.527)$, カーシェアリングと環境 問題 : $\mathrm{t}=0.97(\mathrm{p}=.334))$ 両駅を合わせて情報による関心度 の差異を検討することとした . 図-1 に示す結果より， 双方の平均值がともに中央值の 3 を超えており，どちら の情報も人々の興味喚起につながったことが伺える . ま た，両者を比較するため，平均值の差の $\mathrm{t}$ 検定を実施し た結果，図-1に示すように，費用削減の個人的メリッ 卜情報よりも，CO2 削減の社会的メリット情報の方が $0.1 \%$ 水準で有意に高いことか確認できる．つまり，“力 ーシェアリングか経済的である”という情報よりも“カ ーシェアリングは環境に優しい”という情報のほうが， より人々の興味を喚起しうる傾向か強い可能性が考えら れる.

（4）カーシェアリンク理解度・加入意向

動機付け冊子の読了後 , “「カーシェアリング」とは どのようなものかわかりましたか?”との文言により， カーシェアリングに対する理解度を，続けて，“「カー シェアリング」に加入してみようか...と思いますがと の文言により，カーシェアリングへの加入意向を尋ねた . 回答結果を表-4, 5 に光れ光れ示す. 表-4より，半数以 上の人が , カーシェアリングを「よくわかつた」と回答 
表 4 カーシェアリンク理解度

\begin{tabular}{|c|c|c|c|c|c|c|}
\hline & \multicolumn{2}{|c|}{ 橋本駅 } & \multicolumn{2}{|c|}{ 相模大野駅 } & \multicolumn{2}{|c|}{ 合計 } \\
\hline & $\mathrm{N}$ & $\%$ & $\mathrm{~N}$ & $\%$ & $\mathrm{~N}$ & $\%$ \\
\hline よくわかった & 32 & $49.23 \%$ & 72 & $62.61 \%$ & 104 & $57.78 \%$ \\
\hline 少しわかった & 29 & $44.62 \%$ & 41 & $35.65 \%$ & 70 & $38.89 \%$ \\
\hline よくわからなかつた & 4 & $6.15 \%$ & 2 & $1.74 \%$ & 6 & $3.33 \%$ \\
\hline 合計 & 65 & $100 \%$ & 115 & $100 \%$ & 180 & $100 \%$ \\
\hline & & & & $x^{2}=4.5$ & $p=.10)$ & \\
\hline
\end{tabular}

表 5 カーシェアリング加入意向

\begin{tabular}{r|c|c|c|c|c|c|}
\hline & \multicolumn{3}{c}{ 橋本駅 } & \multicolumn{2}{c|}{ 相模大野駅 } & \multicolumn{2}{c|}{ 合計 } \\
\hline & $\mathrm{N}$ & $\%$ & $\mathrm{~N}$ & $\%$ & $\mathrm{~N}$ & $\%$ \\
\hline まったくい & 16 & $25.00 \%$ & 29 & $26.13 \%$ & 45 & $25.71 \%$ \\
\hline ほんの少しならある & 34 & $53.13 \%$ & 59 & $53.15 \%$ & 93 & $53.14 \%$ \\
\hline ある & 13 & $20.31 \%$ & 21 & $18.92 \%$ & 34 & $19.43 \%$ \\
\hline 十分ある & 1 & $1.56 \%$ & 2 & $1.80 \%$ & 3 & $1.71 \%$ \\
\hline & 64 & $100 \%$ & 111 & $100 \%$ & 175 & $100 \%$ \\
\hline 合計 & & & & $x^{2}=0.07$ & $(\mathrm{p}=.99)$ & \\
\hline
\end{tabular}

しており，「少しわかった」と回答した人を含めると， ほとんどの人がカーシェアリングを理解したと考えられ る.(2)て述べたカーシェアリンク認知度に関して，も ともと「知っていた」人が $30 \%$ 程度, 「全く知らなか つた」人が $35 \%$ 程度であったことを踏まえれば，ワン ショット TFP によってカーシェアリングについての理 解が大幅に促進されたと考えることか出来る.なお, 統 計的有意差は確認されていないものの, 相模大野駅の方 か橋本駅に比べ, 「よくわかった」と回答する人の割合 か大きく，「よくわからなかった」と回答する人の割合 が小さなっており，理解度が高いことが伺える．

一方, 表-5 より, カーシェアリングへの加入意向に つて，「少しなら，弚う思う」と回答した人を含める と全体の $3 / 4$ 程度がカーシェアリングに加入してみよう か，と思うようになっている.このことから，ワンショ ット TFP により人々の加入意向が活性化されているこ とが分かる.なお，駅間において回答結果に統計的差異 はみられていない .

\section{（5）カーシェアリンク加入可能性}

続いて，表-6 に示すような自動車購入に関わる計 4 時点におけるカーシェアリングへの加入可能性を尋ねた . 手順は, まず，「今後」のカーシェアリンク加入可能性 について尋ね, 弚の後, 世帯(または事業所)の自動車保 有台数を尋ねた .ここで自動車非保有者に対しては, ク ルマを新たに購入する予定の有無を尋ね, 予定がある場 合には, 光の購入時期を尋ねることを通じ，光の時点を 想起させ,「新規購入時」のカーシェアリンク加入可能 性を尋ねた。一方, 自動車保有者に対しては, 「現在の 代替」のカーシェアリンク加入可能性を尋ね, 弚の後, 次のクルマ買換予定時期について尋ねることを通じ , 買 換時を想起させ，「買換時」のカーシェアリンク加入可 能性を尋ねた . 光して, さらにもう 1 台クルマを購入す る予定の有無について尋ね，予定がある場合には，弚の 購入時期を尋ねることを通じ，光の時点を想起させ，

「増車時」のカーシェアリンク加入可能性を尋ねた . な お, 各時点のカーシェアリンク加入可能性について, 駅
表- 6 各時点におけるカーシェアリンク加入可能性 質問文

\begin{tabular}{|c|c|}
\hline 略称 & 質問文 \\
\hline 今後 & $\begin{array}{l}\text { 今後、カーシェアリングに加入する可能性、 } \\
\text { は少しでもあり方うですか? }\end{array}$ \\
\hline 現在の代替 & $\begin{array}{l}\text { 現在お持ちのクルマの代わり」に、カーシェアリングに } \\
\text { 加入する可能性は、少しでもあり光うですか? }\end{array}$ \\
\hline 買換時 & $\begin{array}{l}\text { 買換のとき } \text { 次のクルマを購入する代わりにに、カーシェ } \\
\text { アリグに加入する可能性は、少しでもあり关うですか？ }\end{array}$ \\
\hline $\begin{array}{l}\text { 増車時/ } \\
\text { 新規購入時 }\end{array}$ & 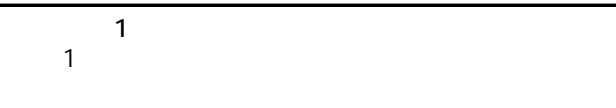 \\
\hline
\end{tabular}

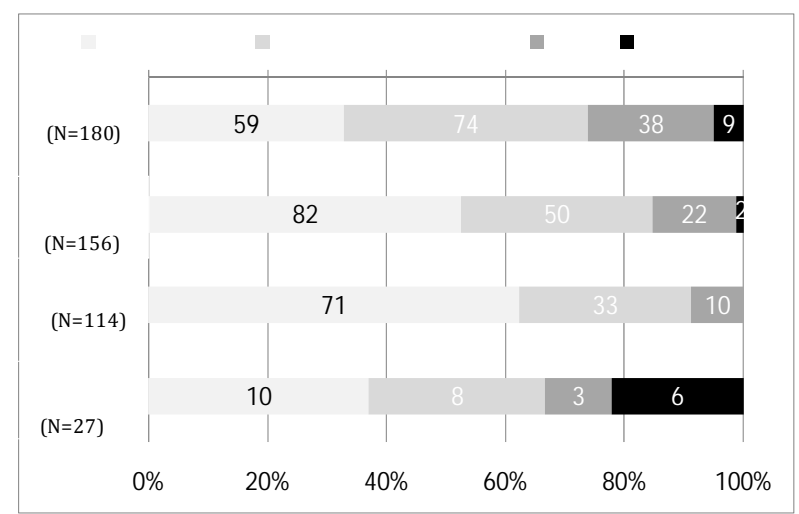

図 2 各時点におけるカーシェアリンク加入可能性 回答結果

表- 7 増車時/新規購入時カーシェアリング加入可能性

回答結果 保有台数別内訳

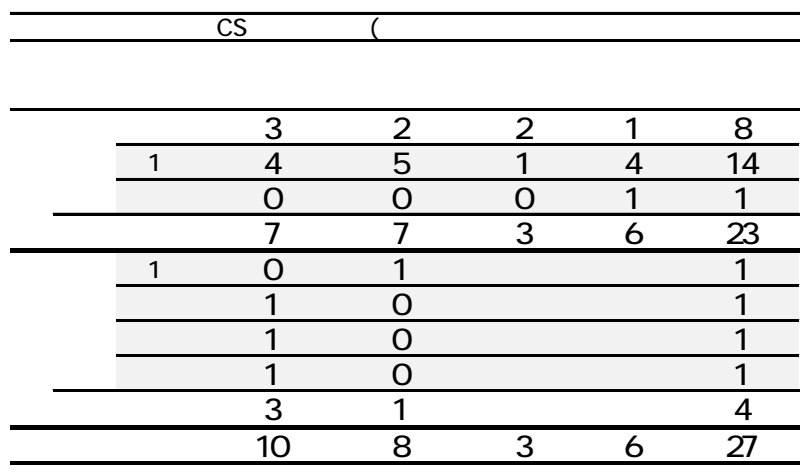

間における回答分布に対し統計的差異 $\left(x^{2}\right.$ 検定による) は確認されなかったため, 以降で両駅を合わせて分析 することとする．

各時点における , カーシェアリンク加入可能性につい ての回答結果を図-2 に示す. 図-2 より，「現在の代 替」や「買換時」といった時点においては, “全くない” の割合が半数以上を占めている.一方で，「増車時/新 規購入時」においては，“十分にある”と回答した者が 6 名存在しており，割合として全体の 2 割程度を占めてい る.なお，表-7 に示す「増車時/新規購入時」における 自動車保有台数別の加入可能性回答結果に着目すると， “十分にある”と回答した者のうち $2 / 3$ はクルマを 1 台保 有している世帯に属していることから，既にクルマを 1 台保有しており，さらにセカンドカ一の購入を検討して いる場合，光の代わりとしてカーシェアリングに加入す 
表- 8 カーシェアリンク関心度 回答結果

\begin{tabular}{|c|c|c|c|c|c|c|}
\hline & \multicolumn{2}{|c|}{ 橋本駅 } & \multicolumn{2}{|c|}{ 相模大野駅 } & \multicolumn{2}{|c|}{ 合計 } \\
\hline & $\mathrm{N}$ & $\%$ & $\mathrm{~N}$ & $\%$ & $\mathrm{~N}$ & $\%$ \\
\hline まったく、関心なし & 15 & $22.73 \%$ & 29 & $25.22 \%$ & 44 & $24.31 \%$ \\
\hline 少しなら、関心がある & 27 & $40.91 \%$ & 48 & $41.74 \%$ & 75 & $41.44 \%$ \\
\hline 関心がある & 16 & $24.24 \%$ & 27 & $23.48 \%$ & 43 & $23.76 \%$ \\
\hline とても、関心がある & 8 & $12.12 \%$ & 11 & $9.57 \%$ & 19 & $10.50 \%$ \\
\hline 合計 & 66 & $100 \%$ & 115 & $100 \%$ & 181 & $100 \%$ \\
\hline & & & & 2 & $=.94$ & \\
\hline
\end{tabular}

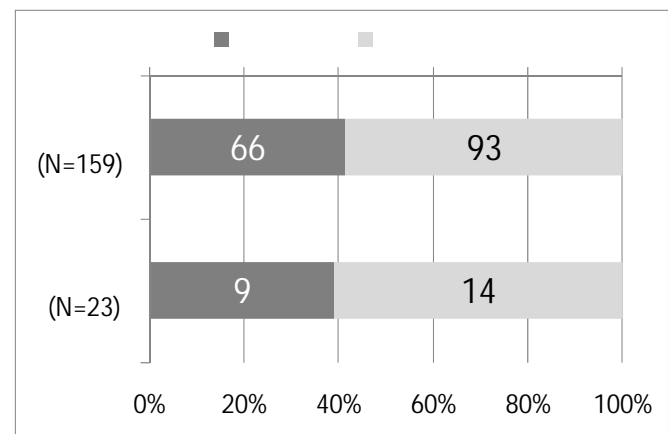

図－３ーシェアリンク詳細資料希望者数

る可能性か高いことが伺える .なお，事業所の場合は， 自動車の必要性か十分に高いか故に増車を検討すると考 えられるため, 一般世帯力圷曽車する状況とは異なり，加 入可能性力比較的低くなっているものと考えられる.

このように , 現在のクルマ, または買換のクルマの代 替として , 人々がカーシェアリングに加入する可能性は 他の時点と比べ低いものの, クルマを新たに増やす場合 において, 兴のクルマの代替として, 人々がカーシェア リングに加入する可能性は相対的に高い水準にあるもの と考えられる. 弚のため, まずは, セカンドカーとして カーシェアリングの普及促進を進めていくことか望まし いと考えられる.ただし , データ数が少ないことからも 分かるようにこうした機会は限定的である点にも留意が 必要である。

\section{（6）実際のカーシェアリングシステムへの関心}

最後に, “今年の 1 月より，橋本駅（または相模大野 駅) 周辺に「カーシェアリング」のシステムか薄入され ました .こ関心はありますか?”と関心度を尋ねた . 回 答結果を表-8 に示す. 表-8 より, カーシェアリングへ の関心が少なくともある人は全体の $3 / 4$ 程度存在するこ とか確忍できる .さらには, “とても関心がある”と回答 した人も 19 名 (10.5\%) おり, 実際のカーシェアリング 加入に対する潜在需要者か十分に存在しているものと考 えられる.なお，回答分布と駅間による統計的差異は確 認されていない .

また , 少しでも“関心がある”と回答した人に対し, 希 望者には, 最寄り駅周辺のカーシェアリングについての 詳細情報を送付する旨を伝え, 希望する場合には, 送付 先の住所, およひ氏名の記入を要請した . 資料送付希望 者数を図-3に示す.なお, 図中では, 資料送付先の住
所等か記入されていた件数を「請求あり」, 送付先, 氏 名か記入されていない場合を「請求なし」と表記した。 图-3 より, 資料送付希望者は, 居住者では 66 件, 事業 所では 9 件と，アンケート回答者のうち 4 害裎度を占め ている . アンケート配布数が両駅をあわせ , 世帯では 1400 件, 事業所ては 136 件であるため, 配布数に対す る反応率は，およ光 $5 \%$ 程度であった . なお，TFP 効果 計測のため，予め設定した「チラシ群」「制御群」にお いて，TFP 群と同樣に700世帯を光れ光れ設定していた にも関わらず, 資料請求があつたのは, 制御群は 0 件， 相模大野駅周辺の「チラシ群」における居住者からの 2 件のみであり，TFP 群の兴机に比べて大幅に低い水準で あったことから，ワンショット TFP によってカーシェ アリングに対する関心か促進され，実際の資料請求とい う実行意図の活性化もか促されたことか沶されたと考え られる. 弚れに併せて, チラシ群からの資料請求が 2 件 であり，制御群よりもわずかに上回る件数であつたが， 上記のように，TFP 群の弚れに比して大きく下回る水準 であることから，チラシ配布の効果は，限定的であると いうことが示された . この点から , チラシよりもワンシ ヨット TFP の方がより加入促進効果か大きいことか改 めて確忍された .

\section{4. 総括}

（1）カーシェアリンク加入促進 TFPの心理的効果

今回の実験では, カーシェアリングの導入か社会実験 に伴うものであったこともあり，短期間でカーシェアリ ングのデポの撤退を余儀なくされたという背景から, カ ーシェアリンク加入促進 TFP の実際の加入行動に対す る効果について明確な分析を行うことは出来なかった。 しかしながら，返送されたコミュニケーション・アンケ 一トの回答結果より, ワンショット TFP によって, カ ーシェアリングに対する理解が大幅に増進することや， カーシェアリングへの関心が促進されるといったような 心的効果力確認された . また, 居住地 (事業所) 付近の カーシェアリングについての関心や, 兴の後の詳細資料 希望数等を鑑みれば, カーシェアリングを事業として実 施するにあたり十分な゙潜在需要か存在している可能性が 伺える.一方で, 先行研究らで得られた知見と同樣に， いまだ，カーシェアリングに対する認知度は低し 状況で あることから，今後はカーシェアリングとのものの認知 度や理解を広めていくためにも，今回実施した TFP の ような個別的なコミュニケーション施策とマスコミ等を 用いた大規模なコミュニケーション施策とを適切に組み 合わせていくことが重要であると考えられる .

さらには, アンケート回答の分析結果より，「カー シェアリングは経済的」というよりも「カーシェアリン グは環境に優しい」という点に人々は強い関心があるこ 
とや , カーシェアリンク加入意向は買換の時点ではなく， 増車の時点で高い，といったようなカーシェアリングの 普及促進に資する基礎的知見が得られた，光のため，今 後カーシェアリングの効率的な普及を図るにあたり，環 境面でのメリットを強調することや, セカンドカーや新 規購入自動車の代替としての普及を図ることか効果的で あると考えられる .

\section{(2) おわりに}

MM の目標である「かしこくクルマとつきあう社 会」の実現を目指す上では, クルマか現実に存在し， 人々のモビリティの一部を支えているという事実がある 以上，「クルマの使い方产のもの」を視野に入れざるを 得ないところであろう. 弚の視点て考えたとき，「クル マの使い方弚のもの」を見直すカーシェアリングは， MM における重要な一つのアプローチとなる可能性が あるものと考えられる . 今回の事例では, とりわけ「資 料請求」というカーシェアリンク加入に向けた具体的な 一つの行動を大きく活性化させたことが示されており，

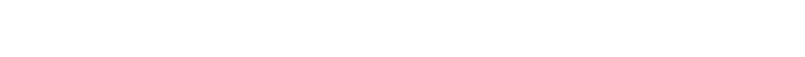
れまでの MM 技術か貢献し得るであろうことを示して いるものと考えられる . 今後は , 今回用いたワンショッ 卜 TFP 技術が, カーシェアリンク普及に実際に資する ことができるか否かの実験を行う等の種々の分析・研究 を重ねつつ, カーシェアリングの普及 ,ひいては, 弚れ を通じてクルマ自体を「かしこく」使う社会状況の実現 の方途を検討していくことが必要であると考えられる．
参考文献

1) (社)土木学会 : モビリティ・マネジメント(MM)の手引き， 土木学会, 2005.

2) 鈴木春菜, 谷口綾子, 藤井聡 : 国内TFP事例の態度 ·行動 変容効果についてのメ夕分析, 土木学会論文集D, Vol. 62, No. 4, pp.574-585, 2006.

3）交通エコロジー・モビリティー財団 : カーシェアリングに よる環境負荷低減効果及ひ普及方策検討報告書, 交通工コ ロジー・モビリティー財団 , 2006.

4) Litman, T. : Evaluating Carsharing Benefits, Transportation Research Record, Vol. 1702, pp. 31-35, 2000.

5) Muheim, P. : CarSharing - the key to combined mobility, Swiss Federal Office of Energy, Energie 2000 Motor fuels section, Mobility, 1998.

6) Shaheen, S. A., and Cohen, A. P. : Growth in Worldwide Carsharing: An International Comparison, Transportation Research Record, Vol. 1992, pp. 81-89, 2007.

7) 三井亨保, 外井哲志 : わ力国におけるカーシェアリング事 業の実態, IATTS Review, Vol. 32, No.2, pp.140-148, 2007.

8) 山本俊行, 成頼弓恵, 森川高行 : カーシェアリングが自動 車保有および交通行動に及ぼす影響の分析, 土木計画学研 究・講演集 (CD-ROM), Vol. 34, 2006.

9) 太田裕之, 藤井聡, 西村良博, 小塚みすず : カーシェアリ ング加入促進手法についての実証的基礎研究, 土木学会論 文集D, Vol. 64, No. 4, pp.567-579, 2008.

10) 交通エコロジー・モビリティー財団 : 全国のカーシェアリ ング事例一覧, http://www.ecomo.or.jp/environment /carshare/carshare_list.html (2009,1時点)

11) オリックスカーシェアリング・ホームページ : オリックス 自動車株式会社 , http://www.orix-carsharing.com/

12) 島田絹子, 谷口綾子, 藤井聡 : 高崎市およひ龍ヶ崎市にお ける転入者対象モビリティ・マネジメントの効果分析, 土 木言十画学研究・講演集 (CD-ROM), Vol.35, 2007.

\section{人々の心理要因に着目したカーシェアリングの効果的な加入促進に対する研究*}

太田裕之***藤井聡 $* * * \cdot$ 遠藤弓太郎**** · 土居厚司 $* * * * * *$

「かしこいクルマの使い方」を考えるにあたり，「クルマ高のものをかしこく使う」方向へのアプローチも検 討せざるを得ないところであり, 兴の際, カーシェアリング(以下，CS)は重要な役割を担うと考えられる. 弚こ で，CS 加入促進に対する実証的知見を得ることを目的とし，環境省の「平成 19 年度神奈川県地域における EST モデル事業推進のための普及啓発委託業務」の一環として , 相模原市において , 住民や事業所を対象としたワン ショットTFP を実施した . アンケート結果より，ワンショットTFPによる，CS につてて理解の大幅な増進， CSへの関心の促進といった効果か確認されるとともに，CS 普及促進に資する基礎的知見を得た .

A study of promotion method to encourage carsharing focused on psychological factors*

By Hiroyuki Ohta** $\cdot$ Satoshi FUJII *** $\cdot$ Kotaro ENDO**** $\cdot$ Atsushi DOI*****

To obtain basic knowledge for effective promotion of carsharing, one-shot TFP, which is one of representative measures in mobility management, was conducted in the areas where a carsharing system was introduced for a social experiment. The result of communication questionnaire revealed that one-shot TFP could promote understand toward carsharing and could enhance behavioral intention to join in a carsharing organization. In addition, the results indicated that it might be important for effective promotion to appeal an environmental benefit of carsharing and to target the carowners who want to an additional car. 